\title{
Acute Epiploic Appendicitis: A Diagnostic Dilemma
}

\author{
Epiploik Apandisit; Akuł Batın Tuzağı
}

\author{
Önder LIMON,' Neşe ÇOLAK ORAY, ${ }^{2}$ Başak BAYRAM,, ${ }^{2}$ 'dvan ATilLA² \\ 'Department of Emergency Medicine, Erzincan Mengücek Gazi Training and Research Hospital, Erzincan; \\ ${ }^{2}$ Department of Emergency Medicine, Dokuz Eylül University Faculty of Medicine, İzmir
}

\section{SUMMARY}

Primary epiploic appendicitis, also called appendicitis epiploica, is a rare condition characterized by inflammation of subserosal colonic adipose tissue. Patients with this condition usually present with complaints of sudden onset focal abdominal pain. No specific symptom or pathognomonic physical examination finding differentiates this condition from other acute abdominal pain etiologies. Patients are usually thought to have diverticulitis or appendicitis on initial evaluation. Use of contrast enhanced abdominal computed tomography on patients presenting with acute abdominal pain may reduce unnecessary surgery, hospitalization and health-associated costs by establishing a definite diagnosis, including rare causes of acute abdomen.

Key words: Abdominal computed tomography; abdominal pain; epiploic appendicitis.

\section{ÖZET}

Primer epiploik apandisit, apendiks epiploika olarak adlandırılan ve subserozal yağ dokusunun enflamasyonu ile karakterize, nadir görülen bir durumdur. Hastalar sıklıkla ani başlangıçlı fokal karın ağrısı ile başvururlar. Epiploik apandisiti, diğer abdominopelvik ağrı nedenlerinden ayıran spesifik semptom veya fizik muayene bulgusu yoktur. Hastalarda sıklıkla başlangıçta divertikülit veya apandisit düşünülür. Akut karın ağrısı ile başvuran hastalarda kontrastlı karın bilgisayarlı tomografisinin kullanılması epiploik apandisit gibi nadir tanıların da konmasına yardımcı olarak, gereksiz hastaneye yatış başta olmak üzere gereksiz tedavi ve cerrahi maliyetlerini azaltabilir.

Anahtar sözcükler: Abdominal bilgisayarlı tomografi; abdominal ağrı; epiploik apandisit.

\section{Introduction}

Appendix epiploica is a normal anatomic structure of subserosal colonic adipose tissue, and there are 50 to 100 appendix epiploica located between the ceacum and the rectosigmoid region. Each is $1-2 \mathrm{~cm}$ in size and $2-5 \mathrm{~cm}$ in length, and each has its own arterial and venous supply. Primary epiploic appendicitis is a rare, self-limiting inflammatory condition which results from torsion of the appendix or spontaneous thrombosis of appendical veins. Its secondary form is instigated by other inflammatory causes. ${ }^{[1]}$
Due to its vague clinical presentation and challenging diagnosis, it's a rare diagnosis in an emergency department. Herein, we presented three cases of epiploic appendicitis and discussed problems that we encountered during its diagnosis.

\section{Case 1}

A 51-year-old female patient admitted to the emergency department with abdominal pain, evident for the last four days. Her pain was located in the lower left abdominal quadrant, 
and she had normal bowel habits. She experienced nausea without vomiting, and her pain was not affected by meals. Her medical history was unremarkable except for hypertension. She had rebound tenderness on the lower left quadrant. Other examination findings and vital signs were normal on initial examination. Laboratory investigation results and blood counts were within normal limits. Her abdominal ultrasonographic (US) examination was normal as well. Since her complaints and physical examination findings remained consistent on follow up, an oral and intravenous contrast enhanced computed tomography (CT) was undertaken. The CT scan disclosed an epiploic appendicitis located distal to the descending colon, as well as, segmentary wall thickening and mesenteric irregularities in neighboring anatomic regions (Fig. 1). She was followed conservatively for 24 hours, and her symptoms resolved during clinical follow-up.

\section{Case 2}

A 43-year-old female patient was admitted to the emergency department with a one-day history of left pelvic abdominal pain. She denied nausea and vomiting, and had normal bowel habits. Her medical history was insignificant. Her physical examination revealed pelvic tenderness on the left side but no rebound reaction. Her laboratory and US examination results were within normal limits. Based on her contrast enhanced CT scan, the patient was initially thought to have diverticulitis, and she was hospitalized for parenteral antibiotic treatment. Due to continuing symptoms after two days of appropriate treatment, her initial CT scans were reevaluated by a senior radiologist, and $2 \mathrm{~cm}$ of inflammatory adipose tissue, consistent with epiploic appendicitis, were revealed at the junction of the descending and sigmoid colons (Fig. 2). An inflammatory reaction on the parietal peritoneum overlying the inflammatory segment was also identi-

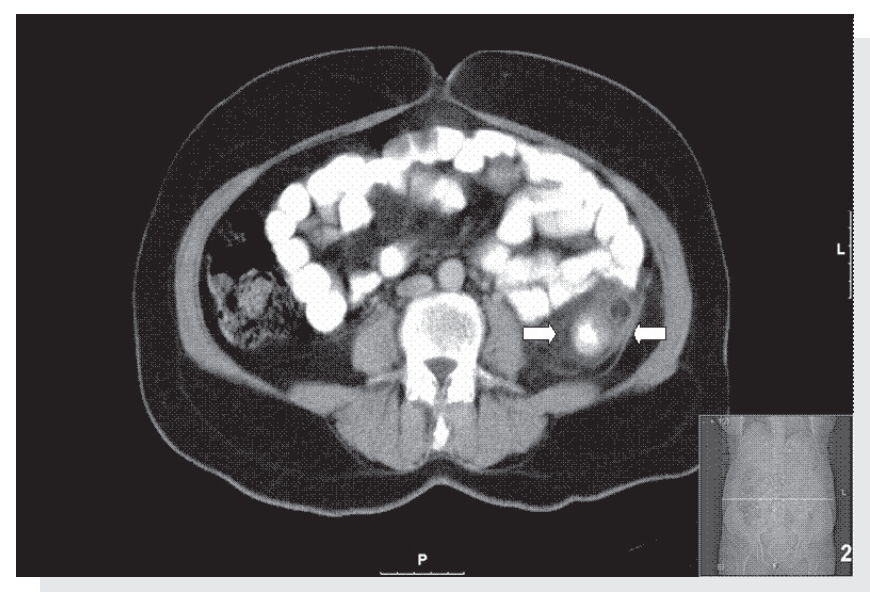

Figure 1. The CT scan shows wall thickening located distal to the descending colon, increased adipose tissue density, and an ovalshaped mass lesion in the paracolic region. fied. On follow-up, her symptoms were resolved without any treatment, and she was discharged in healthy condition the day after.

\section{Case 3}

A 32-year-old male patient was admitted to the emergency department with a one-day history of left abdominal quadrant pain. The patient had experienced no diarrhea, fever, vomiting, or nausea, nor symptoms of respiratory or genitourinary dysfunction. The patient had rebound tenderness on the left lower quadrant. Defense was absent. Other examination findings and vital signs were normal on initial examination. Laboratory investigation results and blood counts were within normal limits. His laboratory and US examination results were also within normal limits. A contrast enhanced CT scan of the abdomen and pelvis was obtained. This revealed inflammatory adipose tissue consistent with epiploic appendicitis located in the descending colon. No diverticuli were noted. The patient was admitted to the hospital for observation with a computed tomography-based diagnosis of epiploic appendicitis. After conservative medical management for 48 hours, he was discharged.

\section{Discussion}

EA is a rare, self-limiting inflammatory disorder which is usually seen in adults aged between 20 and 50 years (Table 1). Certain studies have reported that EA is more prevalent in obese patients. Although it is not a gender specific condition, most reported cases have occurred in males. ${ }^{[1-3]}$ Two of our patients were of the female gender, and one was male. Their ages were consistent with the reported age distribution for the disease.

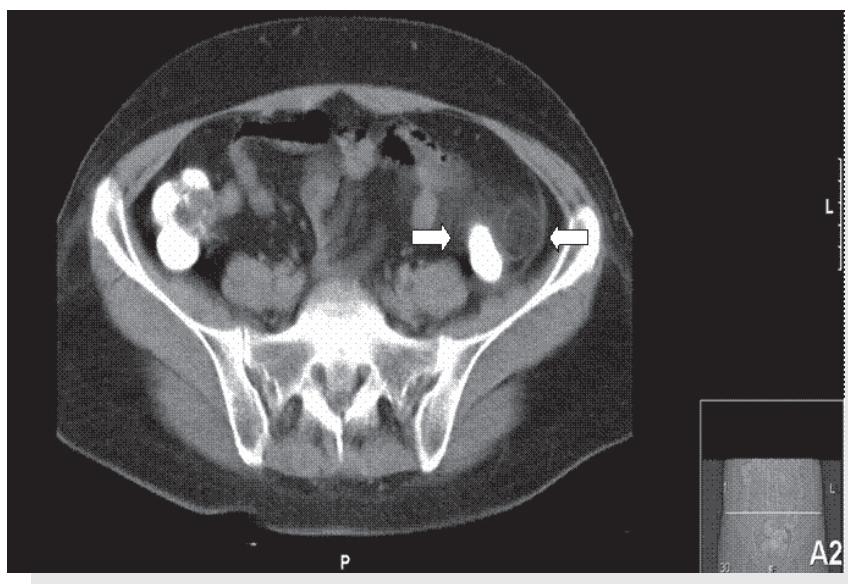

Figure 2. The CT scan shows an epiploic appendicitis located at the junction of the descending and the sigmoid colons. 
Table 1. Summary of data on epiploic appendicitis reported in previous studies

\begin{tabular}{|c|c|c|c|c|c|c|c|}
\hline \multirow[t]{2}{*}{ Authors } & \multirow{2}{*}{$\begin{array}{l}\text { Total } \\
\text { cases no }\end{array}$} & \multicolumn{2}{|c|}{ Gender } & \multirow{2}{*}{$\begin{array}{c}\text { Average } \\
\text { age }\end{array}$} & \multicolumn{3}{|c|}{ Pain locations } \\
\hline & & Male & Female & & $\begin{array}{l}\text { Right lower } \\
\text { quadrant }\end{array}$ & $\begin{array}{l}\text { Left lower } \\
\text { quadrant }\end{array}$ & Others \\
\hline Chen et al. 2011 & 21 & 15 & 6 & 40 & 2 & 17 & 2 \\
\hline Ozdemir et al. 2010 & 12 & 9 & 3 & 40 & 3 & 8 & 2 \\
\hline Bastidas et al. 2008 & 1 & & 1 & 24 & & 1 & \\
\hline Talukdar et al. 2007 & 2 & 2 & & 39.5 & 1 & & 1 \\
\hline Patel et al. 2007 & 1 & 1 & & 29 & & & 1 \\
\hline Sand et al. 2007 & 10 & 7 & 3 & 44.6 & 2 & 8 & \\
\hline Özkurt et al. 2007 & 9 & 5 & 4 & 44.3 & 1 & 5 & 3 \\
\hline Castro García et al. 2006 & 1 & & 1 & 23 & & & 1 \\
\hline Sandrasegaran et al. 2004 & 11 & 5 & 6 & 59.6 & 2 & 4 & 5 \\
\hline Chouillard et al. 2003 & 1 & 1 & & 62 & 1 & & \\
\hline Zissin et al. 2002 & 33 & 24 & 9 & 44.6 & 9 & 21 & 3 \\
\hline Son et al. 2002 & 8 & 8 & & 34.9 & 1 & 7 & \\
\hline Legorne et al. 2002 & 19 & 10 & 9 & 37.8 & 5 & 13 & 1 \\
\hline Halloweger et al. 2002 & 23 & 18 & 5 & 53 & 2 & 21 & \\
\hline Danse et al. 2001 & 10 & 9 & 1 & 35 & 3 & 7 & \\
\hline Hiller et al. 2000 & 5 & 2 & 3 & 47 & & 5 & \\
\hline Birjawi et al. 2000 & 2 & 1 & 1 & 38.5 & 1 & 1 & \\
\hline Horwart et al. 2000 & 55 & 45 & 10 & 39 & 5 & 50 & \\
\hline Vazgueaz friaz et al. 2000 & 1 & & 1 & 63 & & & 1 \\
\hline Vinson et al. 1999 & 2 & 2 & & 38 & & 1 & 1 \\
\hline Vriesman et al. 1999 & 1 & 1 & & 45 & 1 & & \\
\hline Rao et al. 1998 & 11 & 7 & 4 & 45 & 3 & 8 & \\
\hline Molla et al. 1998 & 7 & 3 & 4 & 58 & 1 & 6 & \\
\hline Levret et al. 1998 & 6 & 4 & 2 & 38 & 1 & 5 & \\
\hline Barbier et al. 1998 & 5 & 3 & 2 & 38 & & 5 & \\
\hline Rioux at al. 1994 & 14 & 7 & 7 & 39 & 3 & 11 & \\
\hline Total & 238 & 165 & 73 & 42.5 & 42 & 179 & 17 \\
\hline
\end{tabular}

Most patients with EA present with complaints of suddenonset, well-localized abdominal pain, usually in the left lower abdomen (Table 1). ${ }^{[1-3]} \mathrm{EA}$ is most commonly observed in the descending colon around the iliac fossa. ${ }^{[3]}$ The pain can be sharp, blunt or colicky and deep breathing. Coughing and sneezing may increase the severity of the pain. Although migration of pain is not observed in EA, unlike in acute appendicitis, its localization can be altered by changes in body position due to the movement of the sigmoid colon. ${ }^{[2]}$ Tenderness, rebound and defense are frequent examination findings, whereas abdominal rigidity is a rare finding. Rarely, nausea, vomiting, anorexia, diarrhea, or constipation and mild fever may accompany abdominal pain. However, symptoms tend to be milder for EA patients compared to patients with other acute abdominal pain diagnoses. ${ }^{[2,3]} \mathrm{Di}$ - verticulitis and acute appendicitis (associated with left and right abdominal pain, respectively) are the most common diagnoses confused with EA. Diverticulitis is seen in elderly patients, and pain, fever, nausea, vomiting, and leukocytosis are more marked than in EA. ${ }^{[5]}$ Acute appendicitis usually affects young individuals and is characterized by migratory pain accompanied by anorexia, nausea, vomiting, or constipation. ${ }^{[2]}$ All of our patients had left lower quadrant pain, and their medical histories and physical examinations were not helpful in diagnosing EA.

There are no specific laboratory or imaging modalities for diagnosing EA. EA patients may have mild leukocytosis or normal leukocyte counts. Because of its vague clinical presentation, EA is probably under-diagnosed in emergency 
departments. ${ }^{[3]}$ A definite diagnosis of EA is determined via imaging techniques, including US or CT scans. On US examination, EA appears as a round or oval-shaped, noncompressible, echogenic solid lesion over the painful area. ${ }^{[6,4]}$ Although US is generally accepted as the first modality for the investigation of acute abdomen syndromes, it may not be possible to establish a final diagnosis of EA using this method. Abdominal CT should be the preferred diagnostic tool for determining the etiology of acute abdomen syndromes, unless an etiology is apparent. ${ }^{[4]}$ Increased adipose tissue density, an oval-shaped mass lesion in the paracolic region, and thickening of periappendicial, peritoneal or colonic segments on the CT scan suggest the presence of an EA. ${ }^{[7]}$ In all of our cases, laboratory and US examinations did not deliver definite diagnoses. Definite diagnoses were determined using abdominal $\mathrm{CT}$.

In EA patients, symptoms usually resolve without any treatment within one week. It has been reported that unnecessary surgery and hospitalization are common for patients with EA. ${ }^{[8]}$ Contrast-enhanced abdominal CT is more commonly used in emergency departments so that clinicians can accurately diagnose EA and prevent under-diagnosis. ${ }^{[3]}$

\section{Conclusions}

Use of contrast-enhanced abdominal CT on patients presenting with acute abdomen may prevent unnecessary surgery, hospitalization and health-associated costs by establishing a definite diagnosis, such as EA. During evaluation of the acute abdominal pain, EA should be considered in differential diagnosis, especially for patients with left lower abdominal pain.

\section{Conflict of Interest}

The authors declares no conflict of interest related to this work.

\section{References}

1. O'brien MC. Acute abdominal pain. In: Tintinalli JE, editor. Tintinalli's emergency medicine. A comprehensive study guide. 7th ed., New York: McGraw Hill; p. 527.

2. Vinson DR. Epiploic appendagitis: a new diagnosis for the emergency physician. Two case reports and a review. J Emerg Med 1999;17:827-32.

3. Legome EL, Belton AL, Murray RE, Rao PM, Novelline RA. Epiploic appendagitis: the emergency department presentation. J Emerg Med 2002;22:9-13.

4. Hollerweger $A$, Macheiner $P$, Rettenbacher T, Gritzmann N. Primary epiploic appendagitis: sonographic findings with CT correlation. J Clin Ultrasound 2002;30:481-95.

5. Son HJ, Lee SJ, Lee JH, Kim JS, Kim YH, Rhee PL, et al. Clinical diagnosis of primary epiploic appendagitis: differentiation from acute diverticulitis. J Clin Gastroenterol 2002;34:435-8.

6. de Castro García FJ, Santos Sánchez JA, García Iñigo P, Díez Hernández JC. Epiploic appendicitis. [Article in English, Spanish] Rev Esp Enferm Dig 2006;98:140-2.

7. Ozkurt H, Karatag O, Karaarslan E, Rozanes I, Basak M, Bavbek C. CT findings in epiploic appendagitis. Surgery 2007;141:530-2.

8. Rao PM, Rhea JT, Wittenberg J, Warshaw AL. Misdiagnosis of primary epiploic appendagitis. Am J Surg 1998;176:81-5. 